\title{
SCIENCE IN THE COURT: IS THERE A ROLE FOR ALTERNATIVE DISPUTE RESOLUTION?
}

\author{
Deborah R. Hensler *
}

\section{INTRODUCTION}

For more than a decade, critics of the United States' regulatory and legal systems have asserted that there is a need for new mechanisms to decide the scientific questions that lie at the heart of many public policy disputes over individual and community health and safety issues. In the past several years, concern about "science in the court" has arisen in a new quarter: the practitioner and scholarly community involved with the tort liability system. As a result of changes in legal doctrine and litigation practices, there has been an explosion of tort cases for which scientific questions are central. For example, in the area of medical liability, courts are asked to decide the causal relationship between obstetrics treatment and infant neurological impairments. In the area of products liability, courts are asked to consider the long term effects of drugs and medical devices on the health of those who used them, and sometimes on the health of their offspring as well. In the area of environmental liability, courts are asked to decide the relationship between exposure to toxic substances and the current and future health status of entire communities. These cases have generated significant debate because of the alleged damages to claimants and the huge financial and social costs that are associated with the litigation, and because their substantive outcomes are often very controversial. Although there are many reasons for the problematic character of this litigation, some observers have suggested that the problems associated with these types of cases could be mitigated by modifying court procedures for dealing with the scientific questions on which the cases turn.

Coincidentally, while these substantive developments in tort liability have been taking place, a significant procedural change has occurred in the civil litigation process. Increasingly, alternative dispute resolution ("ADR") mechanisms, such as arbitration and mediation, are being substituted for traditional court decisionmaking processes, such as jury trial. Promoted by lawyers and nonlawyers alike, ADR has burgeoned in both court and noncourt settings. Many proponents of ADR are primarily interested in reducing

Copyright $\odot 1991$ by Law and Contemporary Problems

* Senior Social Scientist, Institute for Civil Justice, RAND, and Visiting Professor of Social Science in Law, University of Southern California Law Center. 
the transaction costs of civil case processing. Most of their attention has been devoted to routine tort cases and contract disputes. But some observers have asked whether ADR procedures might remedy perceived problems in court procedures for dealing with scientific questions in medical malpractice, products liability, and toxic tort litigation.

This article examines this question. Part II reviews the concerns that have been raised about court resolution of scientific issues and the criticisms that have been voiced regarding medical malpractice, products liability, and toxic tort litigation, and identifies the links between these two sets of concerns. Part III reviews the objectives of the ADR movement, describes the major forms of ADR in use today, discusses their use in medical malpractice, products liability, and mass toxic tort cases, and summarizes the empirical evidence on the consequences of utilizing each of these forms for key aspects of dispute resolution. Part IV considers whether and how ADR can contribute to improving court procedures for dealing with scientific questions.

II

\section{The Role of Science in Tort Liability Litigation}

\section{A. Concerns about Science in the Court}

There has been much criticism of the treatment of scientific data and controversies in court settings. Some of this comes from scientists and other professionals who not surprisingly prefer the scientific paradigm for truthseeking to the legal paradigm and believe that the former is more likely than the latter to produce correct judgments on scientific questions. But the revival of the debate about the treatment of science in the court owes much to the key players in high stakes liability litigation: the corporate defendants, insurers, plaintiffs' and defense attorneys, and claimants. For them, how scientific evidence is treated is not an abstract question related to the search for truth but rather a weapon in an adversarial battle. Thus, although the debate over science in the court is often couched in scientific and/or legalistic terms, it has broader ramifications.

Although critiques of the treatment of science in the courtroom are diverse, three classes of concern can be discerned: (1) concerns about the technical credentials of legal decisionmakers; (2) concerns about the legal factfinding process; and (3) concerns about legal decisionmaking rules.

1. Decisionmakers' Credentials. Critics deplore the use of lay jurors and judges without scientific or medical training to decide complex scientific and medical questions. Indeed, some argue that juror selection procedures seem designed to minimize the likelihood of better educated, more technically sophisticated individuals serving on juries. The critique of courts' use of lay decisionmakers is reminiscent of the 1970s critique of regulatory agencies' dependence on politically appointed bureaucrats for decisionmaking on scientific issues, 
which led to calls for a "science court" to resolve such controversies." In the more recent debate, critics have suggested referring scientific aspects of disputes involving multiple claims to specially convened panels comprising appropriate technical experts, ${ }^{2}$ or substituting specially qualified "blue ribbon" juries for lay jurors in individual cases. ${ }^{3}$

2. Legal Factfinding Processes. Many critics assert that the adversarial nature of the legal factfinding process, often characterized as "duelling experts," is inappropriate for assessing the validity of scientific evidence and inferences. Indeed, some say that this process is so at odds with the scientific research approach that it discourages good scientists and physicians from appearing as expert witnesses, leaving the courtroom to "hired guns." 4 In addition, critics believe that scientific evidence often is not properly screened by judges, in part because of their lack of scientific training and in part because of inadequate legal rules for distinguishing acceptable and unacceptable evidence. As a result, say the critics, some of the research that is presented to jurors might more properly be deemed "junk science." 5 To add to these problems, jurors are often prevented from using tools, such as note-taking and questioning, that might aid in understanding complex factual material.

Some critics suggest that these problems could be remedied by using neutral court-appointed expert witnesses; by more aggressive judicial use of the federal rules regarding expert witnesses and evidence; 6 by simplifying the decisionmaking process (for example, requiring juries to consider issues of causation, liability, and damages separately); and/or by allowing juries to use special aids for dealing with complex evidence (for example, permitting juror note-taking and juror questions). All of these actions have been taken by some judges in some jurisdictions, but because they are not in widespread use, some critics have argued for rule changes to provide judges with greater authority to manage the legal factfinding process. ${ }^{7}$ However, those who attribute the problems courts have dealing with scientific questions to the adversarial process itself believe that the problems can only be remedied by denying jury trials in complex cases $^{8}$ or by removing cases such as malpractice and toxic torts from the court system entirely and disposing of them in special

1. James A. Martin, The Proposed "Science Court," 75 Mich L Rev 1058 (1977).

2. Lawrence B. Novey, Handling Causation under Administrative Compensation Programs, in Lawrence B. Novey, ed, Causation and Financial Compensation for Claims of Personal Injury from Toxic Chemical Exposure: Conference Proceedings 323, 326 (Inst Health Policy Analysis, 1985).

3. Note, The Case for Special Juries in Complex Civil Litigation, 89 Yale LJ 1155, 1172-76 (1980) (authored by Charles W. Fournier).

4. Constance Holden, Science in Court, 243 Science 1658 (March 31, 1989).

5. Peter Huber, Junk Science and the Jury, $1990 \mathrm{U}$ Chi Legal F 273; see also Peter Huber, Medical Experts and the Ghost of Galileo, 54 L \& Contemp Probs 119 (Summer 1991).

6. See, for example, Jack B. Weinstein, Improving Expert Testimony, 204 U Richmond L Rev 473 (1986).

7. Tahirih V. Lee, Court-Appointed Experts and Judicial Reluctance: A Proposal to Amend Rule 706 of the Federal Rules of Evidence, 6 Yale L \& Policy Rev 480 (1988).

8. Note, The Right to Jury Trial in Complex Litigation, 92 Harv L Rev 898, 918 (1979). 
administrative systems. ${ }^{9}$ This has already been done at the federal level for vaccine-related injuries ${ }^{10}$ and in Virginia ${ }^{11}$ and Florida ${ }^{12}$ for neurologicallyimpaired baby claims, and the American Medical Association has proposed such a scheme for all malpractice injuries. ${ }^{13}$

3. Decisionmaking Rules. The third line of argument against court proceedings for resolving scientific questions in liability disputes focuses on legal standards of causation. These standards, which juries are instructed to use as grounds for their decisions, are central to the disposition of tort cases, but they are poorly designed, critics say, to deal with the sorts of probabilistic evidence on which many scientific questions turn. ${ }^{14}$

\section{B. Concerns about Liability Litigation}

Policy concern about medical malpractice, products liability, and toxic tort litigation did not initially revolve around scientific questions. Nor is it clear that the accurate resolution of scientific questions-that is, resolutions most consistent with available scientific data-is the highest priority of the parties to these cases. ${ }^{15}$ Rather, these cases have attracted attention because their numbers have grown dramatically compared to rates of growth for other types of tort cases, their outcomes are often unpredictable, the costs to resolve them are sometimes astronomical, and they involve enormous financial and social stakes. ${ }^{16}$

Malpractice litigation has been a recurring concern for policymakers over the past two decades, as both frequency and severity (that is, outcomes) of claims have soared. ${ }^{17}$ In the past several years, concern has centered on claims against obstetricians and gynecologists. ${ }^{18}$ Insurance premiums for these physicians increased dramatically during the late 1980s, attributed in particular to claims involving neurologically impaired infants. As a result, some assert, some obstetrician-gynecologists have left practice, and others

9. Peter Huber, The Bhopalization of U.S. Tort Law, 2 Issues in Science \& Technology 73-82 (1985).

10. National Childhood Vaccine Compensation Act, Pub L No 99-660, 100 Stat 3758 (1986), codified at 42 USC $\$ \S 300$-aa- 10 et seq.

11. Virginia Birth-Related Neurological Injury Compensation Act of 1987, Va Code $\$ \S 38.2$ 5000 to 5021 (1990 \& Supp 1991).

12. Florida Birth-Related Neurological Injury Compensation Plan, Fla Stat $\S 876.301$ et seq (West 1986 \& Supp 1991).

13. A Proposed Alternative to the Civil Justice System for Resolving Medical Liability Disputes (AMA, 1988).

14. See, for example, Troyen A. Brennan, Causal Charts and Statistical Links: The Role of Scientific Uncertainty in Hazardous-Substance Litigation, 73 Cornell L Rev 469 (1988).

15. For a discussion of instances in which "scientific disputes" may mask underlying value conflicts, see Sheila Jasonoff \& Dorothy Nelkin, Science, Technology and the Units of Judicial Competence, 62 ABA J 94 (1982).

16. Deborah R. Hensler, et al, Trends in Tort Litigation: The Story behind the Statistics 10, 28-29, 33 34 (RAND, 1987).

17. 9 Medical Malpractice (US Gen Acct Office, 1986); Report of the Task Force on Medical Liability and Malpractice (US Dep't Health \& Human Services, 1987).

18. Harvard U Div Health Policy, The Medical Malpractice Problem in Obstetrics: The Economic, Medical and Health Policy Implications (Harvard U Press, 1989); Victoria P. Rostrow \& Roger J. Bulger, eds, 2 Medical Professional Liability and the Delivery of Obstetrical Care (Natl Acad Press, 1989). 
have limited their patient population. Although malpractice premiums have stabilized over the past several years, concern about medical malpractice litigation remains great, and Congress is currently considering legislation that would create a "no-fault" system for medical injuries. ${ }^{19}$

In products liability generally, and mass toxic tort litigation in particular, attention has centered on claims involving latent injury. The best known examples of this type of litigation are asbestos worker injury claims, the Vietnam veterans' Agent Orange class action, and personal injury claims arising from the use of the Dalkon Shield, Bendectin, and DES, and exposure to DDT. Some claimants have received large compensation payments, but others with arguably similar injuries and circumstances have received smaller amounts or no payments at all. As a consequence of these claims, a number of large corporations have sought the protection of Chapter 11, and several products have been withdrawn from the marketplace. Many of these products are now generally regarded as unsafe, but some arguably safe products have been withdrawn as well. Legal fees to resolve these cases often dwarf the amounts paid out to successful claimants, and, in some areas of the country, courts have pending caseloads that could occupy them well into the twentyfirst century. ${ }^{20}$

Studies of this type of litigation suggest a number of explanations for its growth, uneven outcomes, delayed dispositions, and high costs. Changes in legal doctrine have increased the likelihood of plaintiff success, making litigation more attractive to claimants and their attorneys. Changes in plaintiffs' attorney litigation practices may also have made it easier to pursue and fund such cases. For example, plaintiffs' attorneys now commonly pool resources and establish coordinating committees to pursue mass litigation against corporations, thereby at least partially offsetting corporate defendants' resource advantages. ${ }^{21}$ Formal legal doctrines and informal court practices that differ across and sometimes even within jurisdictions contribute to outcome variability. For example, the application of statutes of limitations to latent injuries differs among jurisdictions. Within jurisdictions, judges may reach different decisions with regard to the admissibility of key evidence

19. At least five bills related to medical malpractice are currently pending before Congress. See, for example, S 1232 (Medical Injury Compensation Fairness Act of 1991); S 1836 (American Health Quality Act); S 3516 (A bill to award grants to states to promote the development of alternative dispute resolution systems for medical malpractice claims); S 1446 (Health USA Act of 1991); and H 2783 (A bill to direct the Secretary of Health and Human Services to study the feasibility of resolving medical malpractice claims in the same manner as workmen's compensation claims). For several proposed alternatives to litigation for resolving personal injury claims, see Brian McCormick, Tort System Bill Includes New Two Part Resolution Plan, 34 Am Med News 2, 39 (June 24, 1991).

20. For a discussion of problems posed by mass, latent injury claims, see Deborah R. Hensler, et al, Asbestos in the Courts: The Challenge of Mass Toxic Torts (RAND, 1985); Mark A. Peterson \& Molly Selvin, Resolution of Mass Torts: Toward A Framework for Evaluation of Aggregate Procedures (RAND, 1988); Peter Schuck, Agent Orange on Trial: Mass Toxic Disasters in Courts (Harvard U Press, rev ed 1987); Jack B. Weinstein, Preliminary Reflections on the Law's Reaction to Disasters, 11 Colum J Envir L 1 (1986); Ronald Bacigal, The Limits of Litigation: The Dalkon Shield Controversy (Carolina Academic Press, 1990).

21. John C. Coffee, The Regulation of Entrepreneurial Litigation: Balancing Fairness and Efficiency in the Large Class Action, 54 U Chi L Rev 877 (1987); see also Schuck, Agent Orange on Trial at 50-53, 72-76 (cited in note 20). 
and/or expert testimony. ${ }^{22}$ In addition, some plaintiffs' attorneys may purposefully pursue strategies that maximize uncertainty of outcomes. Some courts have difficulty expediting routine civil cases, and sudden bulges in their caseloads due to mass litigation can only exacerbate case delay. Some defendants and their attorneys may purposefully select repetitive litigation strategies that drive up transaction costs and delay payouts. But there is an emerging consensus that the treatment of scientific questions in court proceedings has also contributed to the growth, high costs, delayed dispositions, and uncertain outcomes of this litigation. And there has been a rising chorus of criticism from those who believe that the legal system simply produces too many incorrect decisions in disputes involving scientific issues. ${ }^{23}$

\section{Causation: The Link between Scientists' and Litigators' Concerns}

In all tort claims, the decisionmaker must consider the issue of causation. If the defendant's behavior cannot be linked causally to the plaintiff's injuries, then the defendant cannot be held liable. It is widely agreed that determining causation in toxic tort litigation and certain types of medical malpractice-for example, cases involving neurologically impaired infants-is more difficult than in other, more routine tort cases. ${ }^{24}$ Although these lawsuits differ in many details, most involve an individual claim that the plaintiff was injured at some time in the past by exposure to or use of a particular substance or product, or by a particular medical treatment. Usually the alleged injuries could have been caused by one or more factors not related to the targeted product, substance, or treatment. Often both the evidence that a particular plaintiff's injury was caused by exposure to the specified product or treatment ("specific causation") and the evidence regarding the nature, extent, and future consequences of the plaintiff's injury are disputed. Sometimes the underlying question of whether exposure to this particular substance or treatment causes a particular set of injuries ("general causation") is itself in dispute. As a result, much of the critical evidence in these cases involves medical and scientific research results and their interpretation, the key expert witnesses are likely to be physicians and biomedical scientists, and the final case disposition may turn on the resolution of scientific questions.

Some critics claim that one reason for the growth in such litigation is that judges have been unwilling to dismiss cases in which claims regarding general causation are based on flimsy scientific data, or pseudoscience. Others say that when cases have gone forward, juries have made inaccurate decisions regarding general and/or specific causation. Although the most vocal critics

22. Hensler, et al, Asbestos in the Courts at 48-52, 66-67 (cited in note 20).

23. Peter Huber has been perhaps the most persistent and articulate of these critics. See Peter Huber, Liability: The Legal Revolution and Its Consequences (Basic Books, 1988).

24. There is an extensive literature on causation issues associated with toxic torts. For a description of the variety of issues that arise in determining causation in these sorts of cases, see Troyen A. Brennan, Helping Courts with Toxic Torts, 5 U Pitt L Rev 1, 19-62 (1989). For a discussion of issues related to neurologically impaired infants, see Harvard U Div Health Policy, The Medical Malpractice Crisis in Obstetrics at 53-70 (cited in note 18). 
see these inaccurate verdicts as favoring plaintiffs, thereby encouraging the expansion of scientifically insupportable litigation, jury errors clearly cut both ways. If juries cannot properly assess scientific evidence, they may award compensation where there is no basis for liability; they may also deny it where such a basis exists. But regardless of who is favored in the process, we might expect confusion on the part of juries to increase the variance of outcomes. ${ }^{25}$ Scattered evidence on outcomes suggests that there is significant variance in jury reactions to the same sorts of evidence and experts. ${ }^{26}$

In deciding how much plaintiffs should be awarded, juries may also need to predict the course of plaintiffs' diseases and the likelihood and extent of future impairments. Again, they will be influenced in their decisions by evidence from expert witnesses and constrained by their own abilities to interpret the information presented to them. Some critics see rising average jury verdicts in high stakes cases as evidence that juries' decisions are biased upward. The large variance in the amount of damages awarded in apparently similar cases suggests that juries either have difficulty sorting out the evidence that is presented to them or make their decisions on some other grounds.

Variance in jury outcomes makes it difficult for potential defendants to assess the risks associated with conducting medical practices and manufacturing products. It also challenges many individuals' notions of equity. But variance in jury outcomes in these high stakes cases has other effects as well. Because most cases are not tried, jury awards set benchmarks for settlements. Unpredictability of awards may make it more difficult to negotiate a compromise if each side is imagining an enormously beneficial jury trial outcome that could change the course of future litigation.

Some critics have claimed that current procedures for dealing with scientific questions also contribute to the high cost of this litigation. Some cases involve numerous experts on each side, fees for which may total tens of thousands of dollars per case. Expert witness testimony also extends the length of jury trials, contributing to high court expenditures to resolve these cases. But at least in mass toxic cases, these trial costs are typically amortized over large numbers of claims that are resolved without trial and are probably a tiny fraction of the total public and private costs of processing high stakes cases. The more important costs are those that occur in the lengthy pretrial process.

One aspect of legal treatment of scientific questions that may have a significant effect on transaction costs in high stakes litigation is the difficulty the system has in precluding repetitive litigation of these issues. For example,

25. For an example of jurors' difficulty in understanding the relevance of evidence on smoking for deciding asbestos injury cases, see Molly Selvin \& Larry Picus, The Debate over Jury Performance: Observations from a Recent Asbestos Case xi-xii, 26 (RAND, 1987).

26. For example, a regression analysis of compensation paid to asbestos worker claimants before 1982 could explain only $34 \%$ of the variance in outcomes using case characteristics that are typically viewed as predictive of damages. Tried cases on average received 2.28 times the amount received by settled cases, after taking into account differences in case characteristics. See James $\mathbf{S}$. Kakalik, et al, Variation in Asbestos Litigation Compensation and Expenses 55, 58-59 (RAND, 1984). 
at least in the early years of asbestos litigation, plaintiffs' attorneys had to try the issue of general causation repeatedly, despite the clear scientific consensus that exposure to asbestos is associated with mesothelioma, asbestosis, and lung cancer. Trial court efforts to preclude repetitive litigation of this issue were vetoed by appellate judges. ${ }^{27}$ The issue of whether and when it is appropriate to curtail further litigation on general causation issues is one of the most difficult for those seeking to reform the litigation process. ${ }^{28}$

\section{III}

\section{Alternative Dispute Resolution}

\section{A. History and Objectives of the Alternative Dispute Resolution Movement}

Can alternative dispute resolution procedures improve the courts' handling of scientific disputes? To answer this question, it is necessary to know a little about the history and objectives of the ADR movement. The movement began in the late 1960 s as a populist attempt to return the dispute resolution process to disputants. Early ADR proponents championed mechanisms for taking disputes out of courts, such as neighborhood justice centers. They wanted to substitute mediative processes in which the disputants would fashion a solution to their problem for adjudicative processes that assign control of outcomes to a neutral third party. They believed that through mediative processes, disputants would negotiate outcomes more appropriate to their situation, more satisfactory, and more likely to contribute to the continuation of long-term relationships.

During the 1970s, the ADR movement spread to the courts themselves. Although some proponents of court ADR shared the populist ideals of the movement's founders, most had other objectives in mind. In court settings, ADR became an efficiency mechanism, designed to speed disposition and decrease transaction costs by offering a satisfactory substitute for trial. Perhaps as a result, adjudicative and advisory procedures, such as nonbinding arbitration and summary jury trial, and conciliation processes, such as judicial settlement conferences, have been more popular than mediative procedures, at least with regard to civil suits which include malpractice and toxic torts. Unlike the populist reformers, court reformers did not seek to change either the outcomes of court disputes or the core rules underlying court dispute resolution. Indeed, "court-annexed" procedures frequently have been sold

27. See, for example, Hardy v Johns-Manville Sales Corp., 681 F2d 334 (5th Cir 1982) (denying collateral estoppel on the causation issue). Class certification of asbestos cases has also been rejected. See In re William Temple, 851 F2d 1269 (11th Cir 1988); Waldron v Raymark Industries, Inc., 124 FRD 235 (ND Ga 1989). But see Jenkins v Raymark Industries, Inc., 782 F2d 468 (5th Cir 1986).

28. Hensler, et al, Asbestos in the Courts at 52-67 (cited in note 20). 
to attorneys and repeat-player litigants on the ground that they will not change the overall distribution of case outcomes. ${ }^{29}$

A third stream in the ADR movement, privately contracted resolution of disputes between business and labor and between commercial partners, actually has a longer history than community-based or court-annexed ADR, but until recently received little attention outside the marketplace. Unlike other forms of ADR, these procedures require some prior understanding between the parties about how they will resolve future disputes. ${ }^{30}$

As discussed above, much of the critical rhetoric about the resolution of scientific disputes in court proceedings focuses on the importance of reaching "correct" scientific decisions-and on the structural reasons why courts do not (or cannot) satisfy this objective. It is therefore notable that none of the three varieties of ADR currently receiving attention has as its objective reaching "correct" outcomes, which I define as outcomes that would satisfy an objective neutral standard. The community-based ADR movement seeks to remove or at least minimize the impact of outsiders' standards on dispute outcomes; court-based ADR promises efficiency without changing outcome patterns; and private ADR encourages parties to agree beforehand that they will refer disputes to a mutually acceptable third party-that is, to one whose standards for judging will accord with their own standards, regardless of how these standards might be regarded by an objective outsider. However, ADR mechanisms are distinguished from traditional court proceedings with regard to the three procedural dimensions that concern critics of court handling of scientific issues: decisionmakers, factfinding procedures, and decisionmaking rules. Thus, it seems reasonable to consider the potential of ADR for resolving scientific issues. Below I describe the different ADR procedures, discuss their use to date in medical malpractice, products liability, and mass toxic tort litigation, and review the available empirical evidence regarding their impact on the litigation process. This discussion provides the factual background for Part IV, which considers whether and how well ADR procedures can satisfy the concerns articulated by critics of traditional trial procedures regarding resolution of scientific issues.

\section{B. Varieties and Uses of Alternative Dispute Resolution Procedures}

Although there is a tendency to discuss ADR as if it were a unitary phenomenon, most dispute resolution professionals agree that this is far from

29. For background on the ADR movement and descriptions of ADR procedures, see generally Center for Public Resources, ADR and the Courts: A Manual for Judges and Lawyers (Butterworth, 1989); Stephen B. Goldberg, Eric D. Green \& Frank E. A. Sander, Dispute Resolution (Little, Brown, 1985); Jonathan B. Marks, Earl Johnson, Jr. \& Peter L. Szanten, Dispute Resolution in America: Processes in Evolution (Natl Inst Dispute Resolution, 1984); John Wilkerson, Donovan Leisure Newton and Irvine ADR Practice Manual (Wiley, 1990). On the objectives of court-annexed procedures, see E. Allan Lind, Arbitrating High Stakes Cases: An Evaluation of Court-Annexed Arbitration in a U.S. District Court 7-14 (RAND, 1990).

30. On ADR in commercial contracts, see Robert Coulson, Business Arbitration: What You Need to Know (Am Arb Assn, 1980); Robert Coulson, Business Mediation: What You Need to Know (Am Arb Assn. 1987). 
true. I define ADR (in the litigation context) to include all mechanisms that are designed to reduce the probability of a dispute going to trial through the use of a neutral third party. I then categorize these mechanisms in terms of the role of the neutral third party and the finality of the outcome. In my definition of ADR, I do not include settlement negotiations between the parties without the aid of a neutral third party and outside the context of any formal aggregative procedure such as a class action, since such negotiations do not require any court or other organizational intervention. I also exclude from my definition procedures that are solely intended to expedite or reduce the costs of the pretrial process, such as the use of a special master to manage the discovery process, since they are not formally directed at resolving the dispute. As a practical matter, however, procedures intended to manage the pretrial process may produce a settlement. The discussion below comments on these procedures.

1. Advisory ADR Processes. In advisory ADR processes, a third-party neutral informs the disputants of how a court would be likely to rule on a particular question of law or body of evidence, or how a jury would be likely to decide the case, or some other issue that appears critical to resolution. The advice does not bind the disputants, but if it is delivered by an authoritative figure, such as a court official, or can be entered as evidence at trial, it may have tremendous persuasive power. Advisory procedures may be provided by courts as a voluntary option or may be mandated as a precondition for proceeding to trial. Examples of advisory procedures currently in use include early neutral evaluation panels pioneered in the United States District Court for the Northern District of California, expert panels used by Judge Robert C. Zampano in the District of Connecticut, and summary jury trials initiated by Judge Thomas Lambros in the Northern District of Ohio. Court masters, who have been appointed to help manage many instances of toxic tort litigation, may also be viewed as neutral advisers.

In early neutral evaluation, the parties and their attorneys meet with a court-appointed attorney, ${ }^{31}$ who is chosen for her substantive expertise in the area of the dispute, at an early stage of the litigation process, preferably before much discovery has taken place. The role of the expert is to help the attorneys identify those issues that are critical to resolving the dispute and advise them on an efficient course of discovery. The expert's opinion is confidential and cannot be used at any subsequent trial. ${ }^{32}$ Early neutral evaluation is said to be working well in Northern California, ${ }^{33}$ but only limited empirical data on its effect on the litigation process have been published. There have been no reports to date of its use in cases involving scientific issues.

31. The expert is appointed under the court's authority to appoint masters.

32. Wayne D. Brazil, et al, Early Neutral Evaluation: An Experimental Effort to Expedite Dispute Resolution, 69 Judicature 279, 280 (1986).

33. David I. Levine, Early Neutral Evaluation: A Follow-up Report, 70 Judicature 236, 240 (1987). 
In contrast to early neutral evaluation, expert panels, which are selected by the parties from a list of neutrals provided by the court, are called into play late in the litigation process. Their purpose is to help attorneys, parties, and their experts assess the substantive evidence and the likelihood of success at trial. The substantive experts, who may be scientists or engineers, consider evidence submitted by both sides and may conduct some further investigations on their own. They may also talk ex parte with the judge, parties, parties' counsel, and their experts. The judge then convenes a conference with parties, attorneys, and their experts in attendance, at which the neutral experts give their assessment of the strengths and weaknesses of each side's case. This assessment is then used as a basis for settlement discussions. If the parties do not settle, the neutral experts may appear at trial. ${ }^{34}$

Expert panels do not appear to be widely known outside of the District of Connecticut and do not appear to have been subjected to empirical investigation. Because they are used late in the pretrial process, they are unlikely to have a significant impact on the cost of litigation, but they may allow the parties to reach more mutually satisfactory outcomes. Expert panels have been used in the resolution of complex business disputes, ${ }^{35}$ but to my knowledge they have not been used in cases involving scientific issues.

In summary jury trials, the third-party neutrals are jury pool members, who provide advice on how an actual jury might decide the case. Like the expert panel approach, summary jury trials are usually held late in the litigation process and are intended to influence the disputants' and attorneys' assessments of the likelihood of success. Attorneys for both sides present the key aspects of the case, including substantive evidence, in a highly abbreviated fashion. The jury then deliberates and issues its decision. The decision has no force of law, but may persuade the parties to settle. Some cases do settle after summary jury trials, but others do not. ${ }^{36}$ Judge Enslen has used a summary jury trial to aid in settling a Michigan groundwater contamination case, but they do not appear to have been used very frequently in mass tort cases. $^{37}$ There has been no systematic empirical investigation of the consequences of using summary jury trials. ${ }^{38}$

Medical malpractice screening panels are another advisory procedure that was mandated in some states during the medical malpractice crisis of the mid1970s. In these states plaintiffs were required to bring their claims to panels as either a precondition for filing or a precondition for being placed on the

34. Robert C. Zampano, Settlement Conferences with Experts, in Center for Public Resources, $A D R$ and the Courts at 251 (cited in note 29).

35. Id at 253-54.

36. Thomas D. Lambros, Summary Jun Trial: A Flexible Settlement Alternative, in Center for Public Resources, $A D R$ and the Courts at 79 (cited in note 29).

37. Note, Mandatory Mediation and Summary Jury Trial: Guidelines for Ensuring Fair and Effective Processes, 103 Harv L. Rev 1086, 1089 (1990).

38. Richard Posner, The Summany Jury Trial and Other Methods of Altemative Dispute Resolution: Some Cautionary Observations. $53 \mathrm{U}$ Chi L Rev 366, 374-85 (1986). After noting the lack of systematic research, Judge Posner offers a rough cut at such an analysis, using available data. 
trial list after filing. The panels typically had three to five members, including neutral physicians and attorneys. After hearing the case, the panel would issue a nonbinding decision on liability. As in the case of expert panels, the outcomes of medical malpractice panels could be entered in evidence at a subsequent trial and panel members could be called to testify. The history of medical malpractice panels has been quite troubled. Initially, many jurisdictions had problems implementing the screening panels; as a result, some programs developed considerable backlogs. In many states, panels were subjected to constitutional challenges.

As a result of these administrative and constitutional problems, a number of jurisdictions have formally or informally abandoned their programs. States that have maintained their programs report mixed results: Some claim that smaller, frivolous claims are deterred and that settlement is promoted by panels. Others, however, report continued long delays, high costs, and difficulties finding appropriate experts to serve on panels. ${ }^{39}$ Critics of panels focus on efficiency issues, with little or no reference to whether panels produce outcomes that are more consistent with objective scientific assessments of the clinical evidence than outcomes obtained through more traditional court processes.

2. Conciliation Procedures. In conciliation procedures, the neutral third party encourages the disputants to compromise or conciliate their disputes, but her advice does not bind the parties. As in advisory procedures, if the neutral is an authoritative figure, such as a judge, her advice may be accorded great weight by the parties. And some judges are said to exert considerable pressure on the parties' attorneys in the process of encouraging resolution. Most court settlement programs are conciliation mechanisms.

Settlement programs are probably the most frequently used ADR mechanisms in court settings. In some jurisdictions, they are offered as a voluntary option; in others, they are mandated. They may be scheduled early or late in the pretrial process, as stand-alone procedures or as adjuncts to discovery or motion conferences. They may be governed by court rules or conducted in an ad hoc fashion, at the discretion of a judge. They may be conducted by the judge who will hear the case if it proceeds to trial, by a judge who is regarded as a settlement expert, by a court-appointed master (with or without subject matter expertise), or by volunteer attorneys sitting alone or in panels. Although the settlement process usually occurs within the court, sometimes it is "farmed out" to adjunct programs. Until recently it was quite common to exclude parties from settlement conferences on the ground they would bring up peripheral issues that would complicate resolution. Now some judges are said to be requiring the presence of parties along with their

39. Patricia A. Ebener, Court Efforts to Reduce Pretrial Delay: A National Inventory 56-68 (RAND, 1981); Debra L. Fortenberry, Screening Panels: Corrective Surgery or Amputation?, 4 Ohio St J Dispute Resolution 255-72 (1989). 
attorneys, with the thought that their participation will encourage a more realistic assessment of the likely outcome of the dispute.

By most reports, settlement conferences in routine damage suits are somewhat perfunctory. They focus on the bottom line, seeking a compromise between the plaintiff's demand and the defendant's offer. Although many judges and attorneys who have served as settlement facilitators are enthusiastic about their effects, there is little empirical evidence that these conferences increase the rate of settlement. Many cases do settle at or after settlement conferences, but settlement rates in courts that actively pursue settlement do not appear to be systematically higher than in courts that pursue settlement less aggressively. ${ }^{40}$

In recent years, there have been a number of notable instances of the use of judicial settlement techniques to dispose of mass tort litigation. In these complex cases, the settlement process may range over a variety of issues and a lengthy period of time. To motivate the parties to settle, the judge may meet separately with attorneys for each side and point out weaknesses in their substantive evidence and experts, and vulnerabilities in their legal arguments, while pointing to strengths on the other party's side. In mass tort litigation, it is not uncommon for the judge (or special master) to convene attorneys to develop a settlement agreement that will apply to multiple cases, sometimes numbering in the hundreds. Again, attention focuses on the bottom line, but in these instances that figure is an aggregate sum that will later be disbursed to individual plaintiffs. ${ }^{4}$ Uncertainty about the admissibility and/or weight that will be accorded scientific evidence, if the case were ultimately tried, may be a factor in producing settlements. In the Agent Orange case, for example, Judge Weinstein pressed the defendants to offer a substantial settlement to plaintiffs 42 but later rejected claims of "opt out" plaintiffs on the ground that epidemiologic evidence did not support the finding that Agent Orange was causally linked to the alleged injuries. ${ }^{43}$

In a few notable instances, such as asbestos litigation in the Northern District of Ohio, ${ }^{44}$ the Jenkins asbestos class action in East Texas, ${ }^{45}$ and the Dalkon Shield bankruptcy litigation, ${ }^{46}$ the aggregate bottom line was determined by analyzing the relationship between outcomes in previous cases and the characteristics of the cases at bar, including the nature of the injury

40. For discussions of settlement procedures and consequences, see generally Thomas Church, et al, Justice Delayed: The Pace of Litigation in Urban Trial Courts (Natl Ctr St Courts, 1978); D. Marie Provine, Managing Negotiated Justice: Settlement Procedures in the Courts, 12 Just Sys J 91 (1987); Maurice Rosenberg, The Pretrial Conference and Effective Justice: A Controlled Test in Personal Injury Litigation (Columbia U Press, 1964); H. Lee Sarokin, Justice Rushed is Justice Denied, 38 Rutgers L Rev 431 (1986).

41. Deborah R. Hensler, et al, Asbestos in the Courts at 83-109 (cited in note 20); Schuck, Agent Orange on Trial at 143-67 (cited in note 20); Lucy V. Katz, The L'Ambiance Plaza Mediation: A Case Study in Judicial Settlement of Mass Torts, 5 Ohio St J Dispute Resolution 277 (1990).

42. Schuck, Agent Orange on Trial at 153-56 (cited in note 20).

43. In re Agent Orange Product Liability Litigation, 611 F Supp 1223 (EDNY 1985).

44. In re Ohio Asbestos Litigation, No 83-OAL (ND Ohio, June 1, 1983).

45. Jenkins y Raymark Industries, Inc., 782 F2d 468 (5th Cir 1986).

46. In re A.H. Robins, Inc, 88 BR 742 (ED Va 1988). 
and the quality of clinical evidence. ${ }^{47}$ These results were then used in either a systematic or ad hoc fashion to assess the dollar value of the group of cases at issue. In the DDT class action in Alabama, epidemiological evidence on DDT exposure was combined with clinical test results of plaintiffs to provide a basis for arriving at a settlement amount. ${ }^{48}$ Each of these examples involved an innovative attempt to incorporate medical evidence more systematically in the settlement process. But none of the authors of these procedures has suggested that science was used more appropriately in these cases than in more traditional procedures, or that the outcomes were more scientifically accurate. Moreover, the benchmarks for valuing damages in these cases were the amounts that the attorneys believed would have been obtained had the cases been handled in a more traditional fashion, with all the procedural blemishes that the science critics have noted. In addition, each of these examples involved protracted pretrial litigation and considerable transaction costs. Because none of the efforts has been subjected to empirical investigation, it is impossible to compare their costs or benefits to those of more traditional settlement processes.

Another procedure that should probably be classified as conciliatory is the minitrial. Minitrials have been used in court and noncourt settings, on a voluntary basis, but appear to be more popular outside the court. As in a summary jury trial, the minitrial attorneys on each side present their cases in highly abbreviated fashion. But in minitrials, the attorneys are not speaking to a jury, nor is there any other third-party advisory opinion. Rather, the parties themselves hear the presentation of both sides of the dispute. This process is said to motivate the disputants to talk directly to each other and to promote settlement. As with summary jury trials, the procedure is regarded as particularly appropriate for complex litigation. Most minitrials involve complex business disputes, where the disputants hearing the case are corporate officers. ${ }^{49}$ There is a good deal of anecdotal evidence on the effects of minitrials, but there has been no systematic study of their consequences, nor are there any reports that they have been used to resolve scientific disputes.

3. Mediation. In mediation, the third-party neutral tries to help the parties fashion themselves a mutually acceptable outcome. Often, he will encourage them to articulate the broad range of concerns that may underlie their conflict and to arrive at an integrative solution to their problems. But the third party

47. For a discussion of claims disposition under the Ohio plan, see Francis E. McGovern, Toward a Functional Approach for Managing Complex Litigation, 53 U Chi L Rev 440, 478-90 (19386). For a discussion of claims disposition in Jenkins, see Mark A. Peterson \& Molly Selvin, Resolution of Mass Torts at 39.48 (cited in note 20). For a discussion of Dalkon Shield disposition, see Kenneth $R$. Feinberg, The Dalkon Shield Claimants Trust, 53 L \& Contemp Probs 79 (Autumn 1990).

48. Francis E. McGovern, The Alabama DDT Settlement Fund, 53 L \& Contemp Probs 61, 72-76 (Autumn 1990).

49. Eric D. Green, CPR Minitrial Handbook (Matthew Bender, 1982). For a description of an illustrative minitrial program, see Elizabeth S. Plapinger, The Minitrial in the District of Massachusetts, in Center for Public Resources, ADR and the Courts at 99, 105 (cited in note 34). 
will not himself decide the case. Proponents of mediation believe it is the procedure of choice for disputes that arise between parties that have an interest in preserving a long-term relationship, such as businesses involved in contract disputes. Mediation also has been promoted as a technique for resolving complex public policy and other social issues, where there are many parties' interests at stake. Many mediators believe that participation in mediation should be voluntary and that it should take place outside the court, in a nonadversarial environment. They believe it is a mistake to describe court settlement procedures as mediative. But settlements of tort claims that provide remedies beyond individual monetary damages-for example, by setting up funds for future environmental testing, epidemiological studies, or ongoing physical exams of classes of claimants ${ }^{50}$-might be regarded as integrative solutions. ${ }^{51}$

4. Arbitration. In arbitration, the third-party neutral takes on the role of adjudicator, hearing the case and deciding it. The outcome may be binding, as in private contractual or consensual arbitration, or nonbinding, as in all court-annexed arbitration programs. Usually, if the procedure is outside the court, participation is voluntary: the parties have either contracted in the past to resolve disputes of a particular nature by arbitration, or they make an ad hoc agreement to do so after the dispute arises. Court-annexed arbitration may be voluntary or mandatory, depending on statute or court rule.

Depending on the rules adopted, arbitration procedures may be more or less formal and rules of evidence more or less strict. In court-annexed arbitration, the tendency is to relax the rules that would otherwise apply, since the objective is to provide a less formal, more streamlined alternative to trial. Outside the court, the focus may be more on providing specialized procedural and substantive rules, which are custom-tailored to specific types of disputes.

The most common form of arbitration outside the court is probably commercial arbitration conducted under the aegis of the American Arbitration Association ("AAA"). AAA maintains lists of arbitrators with specialized expertise in various fields and has also developed special rules for resolving certain classes of disputes. Numerous other organizations also provide binding arbitration for various kinds of commercial and insurance disputes outside court settings.

Some health provider organizations require patients to sign agreements to arbitrate disputes that may arise over treatment injuries. Arbitration has also played a role in some mass toxic tort settlements. For example, under the Robins bankruptcy settlement agreement, one option for Dalkon Shield plaintiffs is to refer their claims to arbitration. ${ }^{52}$ The Manville Trust also offers arbitration as an option to asbestos claimants (under the aegis of a

50. The DDT settlement, for example, included a provision for physical exams. McGovern, $53 \mathrm{~L}$ \& Contemp Probs at 64-65 (cited in note 48).

51. Lucy Katz suggests that Judge Zampano used integrative mediation to settle the L'Ambiance Plaza claims. See Katz, 5 Ohio St J Dispute Resolution at $327-28$ (cited in note 41 ).

52. Feinberg, $53 \mathrm{~L} \&$ Contemp Probs at 107-09 (cited in note 47). 
private dispute resolution provider, U.S. Arbitration and Mediation, Inc.) as does the privately subsidized Center for Claims Resolution. ${ }^{53}$ But in both these cases, arbitration is envisaged as a mechanism for assessing damages, not deciding disputes about the underlying scientific issues regarding causation.

Although many proponents of binding arbitration assert that this technique reduces transaction costs, to date there is no empirical evidence to back this claim, and anecdotal data indicate that private arbitration can be a lengthy and expensive process. In the medical malpractice area, arbitration appears to increase frequency of claims and decrease average payouts, with a net effect of increasing total payments. ${ }^{54}$ Arbitration's chief benefit to many disputants may be that it reduces the uncertainty of outcomes by substituting expert decisionmakers for lay juries.

Arbitration has been adopted within court settings primarily as an efficiency mechanism. Most jurisdictions limit arbitration to routine claims for modest dollar amounts, although arbitration for cases up to $\$ 150,000$ is mandated in some federal districts. ${ }^{55}$ Arbitrators are attorneys or retired judges who serve on a voluntary basis. Because many programs restrict jurisdiction to tort cases, the arbitrators may be selected for expertise in this field. Arbitrators sit alone or in panels of two or three. They rarely review materials on the cases before they hear them. The hearings themselves usually take less than an hour, although one study of a federal court's arbitration program found hearings averaged about six hours. ${ }^{56}$ The rules of evidence apply, but in relaxed form, and cases are usually presented "on the papers." If accepted by all sides, the arbitrators' decisions are entered as court judgments, but any party to the dispute is free to reject the award and proceed to trial de novo, and in many jurisdictions the parties reject the outcome in upwards of half the arbitrated cases. Most of these cases later settle without trial. Because it is court-mandated, this sort of arbitration has been subjected to considerable study. The empirical evidence suggests that it does not reduce the public costs of court dispute resolution but may reduce private transaction costs. As anticipated by its proponents, arbitration does not appear to alter the distribution of case outcomes. ${ }^{57}$

For several years the Philadelphia Court of Common Pleas operated a variant of court-annexed arbitration for asbestos cases that mandated bench trials in these cases as a precondition for being placed on the trial list. A small number of judges were selected to preside at these trials, which yielded

53. See Marianna S. Smith, Resolving Asbestos Claims: The Manville Personal Injury Settlement Trust, 53 L \& Contemp Probs 27, 34 (Autumn 1990); Lawrence Fitzpatrick, The Center for Claims Resolution, 53 L \& Contemp Probs 13, 19 (Autumn 1990).

54. Patricia M. Danzon, New Evidence on the Frequency and Severity of Medical Malpractice Claims 21 (RAND, 1986). 404 .

55. Deborah R. Hensler, Court-Ordered Arbitration: An Alternative View, 1990 U Chi Legal F 399,

56. Lind, Arbitrating High-Stakes Cases at 30 (cited in note 29).

57. Id at 44 . 
nonbinding verdicts. The program was intended to expedite settlement, without changing the distribution of outcomes. ${ }^{58}$ Although many cases were processed through the program, the appeal rate was high, and the program was eventually abandoned.

5. Other Uses of ADR: Aggregating Cases for Settlement. History suggests that at some stage in the mass tort litigation process, disputes become ripe for settlement, not because agreement is reached on the substance of the dispute, but rather because each side has arrived at a point where there are more benefits to resolving the litigation than to continuing it. When parties are ready to resolve the underlying litigation, aggregating cases may enhance the likelihood of an integrative resolution of the case, creating a positive environment for mediation. If the ingredients for true mediation are absent, the parties may nonetheless be persuaded to settle by a skilled conciliator. As described above, a variety of conciliatory and mediative techniques have been used to resolve large aggregations of cases, as illustrated in the Agent Orange litigation, Dalkon Shield bankruptcy litigation, and DDT litigation. ${ }^{59}$ Advisory processes, such as summary jury trials, might also be useful at such a stage in providing parties with an indication of the outcomes should mediation fail. Conversely, parties may be loath to use authoritative ADR procedures, such as arbitration, in an aggregative context because combining cases raises the stakes for both sides enormously. Once an overall settlement of a class of litigation has been reached, ADR procedures have the potential for reducing time to disposition and transaction costs in the allocation of damages. ADR procedures modelled after court-annexed arbitration might also enhance claimants' perceptions of procedural fairness by providing a hearing before a neutral third party. ${ }^{60}$ Whether aggregative settlements reduce transaction costs or produce more equitable allocations of damages are currently unanswered questions.

\section{IV}

\section{Resolving Core Scientific Issues: Can ADR Improve Court Handling of Scientific Disputes?}

Part II suggested that critics of current court processes for dealing with the core scientific questions underlying high-stakes liability litigation are dissatisfied with criteria for selecting decisionmakers, factfinding procedures, and decisionmaking rules. Part III discussed the use of ADR procedures, noting that there are few instances in which these techniques have been applied to scientific disputes. To what extent would the ADR procedures

58. Hensler, et al, Asbestos in the Courts at 106-07 (cited in note 20).

59. See generally, for example, Schuck, Agent Orange on Trial (cited in note 20); Bacigal, The Limits of Litigation at 98-115 (cited in note 20); McGovern, 53 L \& Contemp Probs at $61-65$ (cited in note 48 ).

60. The success of such an approach has yet to be demonstrated. ADR procedures envisaged in the Dalkon Shield plan have yet to be implemented, and claimants have recently challenged the proposed ADR rules. In re A.H. Robins, Admin Order No 1 (filed June 26, 1991). 
described in Part III satisfy critics' concerns about litigation of scientific questions?

\section{A. Decisionmakers' Credentials}

Many critics would like to substitute neutral scientific experts or at least more-educated individuals for lay decisionmakers in some stages of the litigation process and with regard to some issues. Few of the ADR procedures currently operating within courts do this. Third-party neutrals are usually generalists or specialists in some aspect of the litigation process, rather than substantive experts. Juries in summary jury trials are not specially qualified; they are selected from the same jury pool that would be used if the case ultimately went to trial. Judges are assigned to settlement programs because of their settlement skills. Lawyers are chosen for court-annexed arbitration panels based on their experience in a certain area of the law. Expert panels are an exception to this rule, but they serve in an advisory rather than decisionmaking capacity, much as any expert does in a trial process.

The fact that current rules for court-annexed ADR programs do not mandate the use of substantive experts does not, of course, preclude experts from participating by stipulation of both parties or under the judges' discretionary authority (although arbitration statutes that require arbitrators to be lawyers might prove an obstacle), and one can, of course, imagine new or revised statutes that would mandate the use of substantive experts under certain conditions. But such changes would run against the mainstream of court-annexed ADR, which seeks to reduce the public costs of the litigation process by substituting minimally reimbursed volunteers for more costly judges, without changing core procedural rules. In addition, although courtannexed ADR has proved popular in state courts, its acceptance may be predicated on the notion that it will be applied only to routine damage suits (such as automobile accident cases) or personalized disputes (such as divorce cases). Resistance to the expansion of arbitration in the federal court system $^{61}$ or beyond fairly modest monetary jurisdictional levels in the state courts, is often justified on the grounds that such procedures are inappropriate for more complex litigation. This perception does not augur well for the application of this procedure to malpractice or toxic tort litigation.

Outside of court settings, there are better opportunities for using neutral scientific experts or others with speciaiized substantive expertise as decisionmakers. When parties voluntarily agree to a particular form of dispute resolution, they are free to choose whatever type of third-party

61. Congress considered legislation to expand mandatory arbitration on at least two occasions. In both 1978 and 1988 , the final versions of the legislation mandated additional pilot testing and research instead of full-scale adoption. See Diane Wood, Court Annexed Arbitration: The Wrong Cure, 1990 U Chi Legal F 432, 435. Generally, public opposition to arbitration has focused on denial of due process to litigants with smaller value claims. Id at 448 . In private, however, practitioners concede that they are opposed to expanding arbitration to include more complex-and more lucrative-litigation. 
neutral they wish. Indeed, as I have suggested, the main appeal of private arbitration may be its use of expert decisionmakers. ${ }^{62}$ The problem with applying voluntary binding arbitration to most product liability or mass tort litigation is that the claimants had no ongoing relationship with the target defendants and thus no opportunity before the fact to enter into an arbitration agreement. Because there is an ongoing relationship between doctors and patients, arbitration may be a more attractive option for dealing with malpractice incidents.

In the absence of a prior agreement to arbitrate, disputants could agree to settle some or all of the issues in contention through binding arbitration. For example, tort litigants could agree to refer the issue of general causation to arbitration. But successful uses of voluntary binding arbitration seem to be predicated on a consensus among a class of disputants (for example, construction firms) about the general principles that ought to guide dispute resolution in their area of activity. As the controversy over scientific causation in mass toxic tort cases and some medical malpractice cases indicates, no such consensus currently exists among the relevant disputants. In mass toxic tort cases, the disputants strongly disagree about the weight of the substantive evidence on critical issues and about the attractiveness of different decisionmaking procedures and rules. As a result, arbitration in those cases has so far been used only for setting individual damages, after the general causation issue has been resolved and criteria for specific causation have been agreed upon.

Absent an externally imposed mandate to refer some or all aspects of such cases to binding ADR, this situation is unlikely to change. The ABA Commission on Mass Torts recently proposed federal legislation that included provisions for expert panels and mandatory alternative dispute resolution. ${ }^{63}$ Some versions of recent draft legislation on product liability also contained provisions for alternative dispute resolution. ${ }^{64}$ But none of these proposals has gained substantial support. ${ }^{65}$

\section{B. Factfinding Procedures}

A broad set of suggestions for change falls within this category, including greater use of neutral experts in both the pretrial and trial process, better screening of scientific experts and evidence, and changes in trial procedures. Within the court setting, both early neutral evaluation and expert panels may be attractive options.

62. See Part III B 4.

63. Report and Recommendations of the Commission on Mass Torts, App D, $\S 108,109$ (ABA, 1989).

64. See, for example, the Product Liability Fairness Act § 202, S 640, 102d Cong 1st Sess (March 13, 1991), in 137 Cong Rec S3191 (March 13, 1991).

65. Despite multiple efforts, product liability legislation has been unsuccessful in Congress. See Linda Upsen, The Evolution of Products Liability as a Federal Issue, in Peter Schuck, ed, Tort Law and the Public Interest 248.61 (W.W. Norton, 1991). The ABA tabled the Mass Torts Commission's report without debate. 
Early neutral evaluation could involve a neutral attorney and one or more scientific experts who would be brought into the litigation process at an early stage to help the attorneys identify the key questions in dispute and fashion a discovery process that would more efficiently develop the evidence necessary to resolve these questions. Because a judge is not involved in early neutral evaluation conferences and the discussions are confidential, attorneys might be less concerned that the proceedings would bias the final outcome of the case. And by focusing the attorneys' attention on the uncertainties related to the scientific questions in a less adversarial framework, early neutral evaluation might improve prospects for settlement. Early neutral evaluation has garnered positive reactions in northern California, in both state and federal courts, and is cited as a model for other courts to follow in a recently issued report by the Brookings Institution. ${ }^{66}$

Expert panels do not have the same potential to promote early settlement and reduce transaction costs, but they are a mecharism for involving neutral experts in both pretrial and trial processes. Because expert panels offer their opinions in the case to attorneys, disputants, and their experts prior to trial, they give the parties a chance to consider not only the substantive advice that they are offering but also the probable influence of this advice on a jury if the case proceeds to trial. Because the parties themselves select the members from lists provided by the court, expert panels may be more acceptable to the adversaries than neutrals appointed by the court alone. Although not as widely known as early neutral evaluation, this procedure too seems worthy of further investigation.

Medical malpractice panels are an obvious mechanism for involving experts in resolving medical disputes. Although they do not appear to have been successful in resolving routine malpractice cases, it might be worthwhile to rethink their role in dealing with more complex claims, such as neurologically-impaired baby claims. A careful examination of the history of malpractice screening panels might suggest ways in which this procedure could be modified to increase its effectiveness and the perceived equity of its outcomes.

Although there has been some debate on this point, there does not appear to be any reason why judges cannot involve neutral experts in pretrial settlement processes, or even during trial, under current rules. As a special master in toxic tort litigation, Francis McGovern has used neutral experts to assist in developing data bases and conducting analyses that provided a basis for settlement discussions. In a case involving Native American tribal water rights, ${ }^{67}$ Professor McGovern used neutral experts to develop a negotiation game to assist in settlement. ${ }^{68}$ In the Ohio and Jenkins class action asbestos

66. Civil Justice Reform Task Force, Justice for All: Reducing Costs and Delay in Civil Litigation (Brookings Inst, 1989).

67. Indian Tribes' Amended Motion to Allocate Resources, U.S. $v$ Michigan, Civil Action No M26-73 (WD Mich, April 25, 1984).

68. McGovern, 53 U Chi L Rev at 46I-65 (cited in note 47). 
litigation, he used experts to develop analytic models to assist in settlement. ${ }^{69}$ Although all of these procedures were ad hoc, there may be good reasons for pursuing reform on a case-by-case basis, as Professor McGovern has done, rather than pressing for a comprehensive modification of the tort system.

Because court-annexed arbitration is designed to streamline the evidentiary process, it does not appear to be an attractive mechanism for strengthening scientific evidentiary and expert standards.

Although not generally thought of as ADR mechanisms, there are variations on traditional trial procedures that attempt to deal with some of the critics' concerns about jury decisionmaking on scientific questions. Consolidated trials are an approach to reducing repetitive litigation of general causation issues. Consolidation has been used by Judge Carl Rubin in the Bendectin litigation and by Judge Robert Parker in asbestos litigation, among others. ${ }^{70}$ Bifurcation and trifurcation have been used to separate general causation, liability, and damage issues for trial and some judges have used reverse bifurcation (trying damages first). ${ }^{71} \mathrm{~A}$ recent experimental study suggests that these procedures may have significant effects on the distribution of outcomes, ${ }^{72}$ but whether they deliver more scientifically accurate decisions is a matter of some dispute. Adoption of all of these procedures appears to be within the judges' discretionary power, and judges are displaying increasing willingness to use such techniques in complex litigation.

Disputants can custom tailor private ADR procedures to include or exclude scientific experts and/or evidence. The only requirements would seem to be that the disputants agree to the rules and that basic standards of due process are met. Just as AAA has developed special rules for particular types of commercial arbitration, it might be possible to develop model rules for resolving science-related disputes. In the case of commercial arbitration, this apparently has been an evolutionary and consensual process, which builds upon ongoing relationships within the business community. As discussed above, absent an external mandate, it is not clear that medical malpractice or toxic tort litigation has the ingredients to bring about such consensual agreements.

\section{Decisionmaking Rules}

Decisionmaking rules are incorporated explicitly in formal legal doctrine and implicitly in informal practice and standards for assessing outcomes. Some court critics would like to change legal rules for dealing with

69. See id at 487-89; Francis E. McGovern, Resolving Mature Mass Tort Litigation, 69 BU L Rev $659,669-71(1989)$.

70. See, respectively, In re Richardson-Merrill, Inc., "Bendectin" Products Liability Litigation, 624 F Supp 1212, Civil Action No B086-0456-CA (ED Tex, Nov 12, 1990) and In re Ohio Asbestos Litigation, 1990 WL 135753 (ND Ohio).

71. The Philadelphia Court of Common Pleas used such reverse bifurcation in its asbestos bench trial program. See Hensler, et al, Asbestos in the Courts at 106 (cited in note 20).

72. Irwin Horowitz \& Kenneth S. Bordens, An Experimental Investigation of Procedural Issues in Complex Tort Trials, 14 L \& Human Behavior 269 (1990). 
probabilistic data and uncertainty. If current rules are responsible for inaccurate or highly variable outcomes, then the effectiveness of such changes would presumably be assessed by examining changes in the distribution of outcomes.

No ADR procedure currently operating within court settings has the explicit objective of changing these or other aspects of legal doctrine. In advisory and conciliatory processes, third-party neutrals accept court doctrine as given and attempt to help the parties understand the implications of these doctrines for developing and trying their cases. Moreover, many of these processes deliberately try to incorporate the dynamics of current jury decisionmaking. For example, summary jury trials offer the disputants a preview of what a jury's decision might be if the case actually went to trial. Settlement judges and masters remind the attorneys of the vagaries of jury decisionmaking as a prod to induce settlements. Court-annexed arbitration is judged as a success when the distribution of awards mimics the distribution of trial verdicts. Even the more innovative procedures developed for asbestos and Bendectin cases use outcomes of the traditional system (that is, the litigation before the inception of the innovation) as the benchmarks for valuing cases. For example, the Center for Claims Resolution, which is a privately subsidized mechanism for disposing of asbestos cases, uses jury verdicts as the benchmarks for settlement offers. ${ }^{73}$ The prevalence of such practices demonstrates the strength of the jury paradigm among participants in the liability system.

Among ADR procedures outside court settings, there is more variety in decisionmaking rules and standards for assessing outcomes. Private commercial arbitration operates under its own rules; its outcomes are not a matter of public record and therefore are not subject to assessment against an external standard. Minitrials seem to be an attempt to break away from the litigation process entirely by bringing business decisionmakers into the dispute resolution process and encouraging them to substitute business criteria for legal standards in resolving their disputes. True mediative processes attempt to assist disputants in developing their own criteria for a satisfactory dispute outcome. But, as stated before, absent an external mandate, it seems unlikely that the parties in toxic tort litigation would agree to adopt such procedures, as long as the underlying issues in contention remain unresolved. An exception to this proposition might be a situation in which community residents are concerned about danger to health and safety from some local toxic exposure. If representatives of the facility that is the source of concern were to meet with residents before litigation was filed, perhaps satisfactory solutions could be fashioned. For example, additional environmental tests might be carried cut, and residents might be offered subsidized medical examinations. Mediation might be most appropriate

73. Fitzpatrick, 53 L \& Contemp Probs at 21 (cited in note 53). 
under these circumstances; indeed, mediation appears to have been used successfully in situations involving Superfund sites.

\section{$\mathrm{V}$ \\ Conclusion}

In sum, current forms of ADR appear to have limited utility for resolving the core scientific questions that underlie mass toxic tort litigation and certain medical malpractice disputes. Within court settings, ADR procedures do not use experts as decisionmakers and do not attempt to change decisionmaking rules. When evidentiary procedures are incorporated in court ADR procedures, the tendency is to relax evidentiary standards rather than strengthen them. But some ADR procedures, particularly early neutral evaluation, expert panels, and medical malpractice screening panels, may offer opportunities for expanding the role of neutral experts in the litigation process.

Most in-court innovation regarding the treatment of scientific disputes has been brought about by judges, acting under traditional rules and exercising their discretionary powers, rather than through adoption of a comprehensive ADR program. It may be easier for judges to obtain agreement to innovate from parties on a case-by-case basis than it would be to obtain a political consensus to adopt any particular ADR plan, especially if that plan were to be implemented outside the direct scrutiny of a judge.

ADR procedures operating outside court settings appear to have more utility for resolving scientific disputes. They frequently use expert decisionmakers, have developed special procedural rules for resolving complex disputes, and have the capacity to incorporate various kinds of scientific evidence and expert advisers. Although general principles of due process apply to these procedures, they offer an opportunity to develop new decisionmaking standards. But these procedures can be applied only with the agreement of the disputants, and the most successful procedures have developed in an evolutionary and consensual fashion as a result of long-term relationships between the parties. Absent some external mandate, it seems unlikely that the major players in tort litigation would agree to a wholesale transfer of their disputes to such private forums. In specific cases, disputants have agreed to use innovative ADR procedures for resolving some aspects of their cases. But removal of cases to private ADR has generally occurred after resolution of the underlying dispute, including scientific issues, within court settings. An exception to this general proposition might be prelitigation situations where the "plaintiffs" see themselves as acting on behalf of a community or worker interest in promoting health and safety, rather than as individual claimants seeking damages for past injuries. In these situations, true mediation may be both appropriate and acceptable. 
